\title{
THE NATURE AND EFFECT OF CONSERVATION ORDERS AND POSSIBLE CIVIL LIABILITIES THAT MAY RESULT FROM VIOLA- TIONS OF CONSERVATION ORDERS
}

\author{
R. N. OSTROSSER *
}

\begin{abstract}
An oil operator is subject to a vast number of conservation orders in the conduct of his oil and gas operations. This article considers the civil liabilities that an operator may be subject to for breach of a conservation order. It suggests that with respect to liability to a third party for breach of a conservation order, an operator may be liable on the basis of a breach of statutory duty, or alternatively, the breach of the conservation order may be considered as evidence of negligence per se. With respect to contractual liability to his lessor or to other contracting parties, this article advises that a violation of a conservation order might constitute a breach of contract.
\end{abstract}

\section{A. INTRODUCTION}

While United States' authors invariably comment upon the profound effect that conservation laws and orders have had upon contractual and property rights within the oil and gas industry in the United States, the same assessment of the impact of conservation laws and orders cannot be made of the oil and gas industry in Western Canada. This result follows, of course, by reason of the fact that the major growth and expansion in our industry did not commence until the late 1940's, by which time the impact of conservation legislation in the United States on the law of capture and the development theory was evident. We, in Western Canada, have thus to a large extent been spared the disruptive process of reconciling earlier concepts of contractual and property rights with present day conservation legislation.

The title to this paper involves a consideration of what are in effect several separate subjects. Of necessity therefore, this paper cannot be and is not intended to be an analytical source study of the various topics to be discussed. Instead, it will be limited to a summary of the subjects and the principles involved. It is hoped that in this way it will alert the reader to the questions and principles involved. The paper will commence with a brief review of the various types of conservation orders, the nature and effect of these orders, and of possible civil liabilities arising from either violation of or compliance with conservation orders. The paper will not consider the effect of conservation orders on implied covenants in oil and gas leases, per se, although this is a subject in Canada which appears to merit research and comment.

\section{B. GENERAL NATURE AND EFFECT OF CONSERVATION ORDERS}

The term "conservation order" as used herein will, unless the context otherwise requires, include all types of rules, regulations and orders issued under the conservation statutes. Conservation orders have been classified according to their effect as follows:

(a) Regulatory orders-This type of order is simply regulatory or in restraint of future conduct. Under such an order a person,

- Solicitor, Sun Oil Company, Calgary, Alberta. 
while not required to act, must, if he chooses to act, conform to the requirements of the order.

(b) Affirmative orders-This type of order requires that a person carry out a specific act, such as the plugging of a well.

(c) Adjudicatory order-This type of order as it suggests, determines or adjudicates the rights of parties as an incident to regulatory or pooling orders, for example, the acreage attributable to a well for allowable purposes. ${ }^{1}$

The classification of conservation orders as either legislative, judicial or quasi-judicial is difficult. Canadian courts have displayed a greater tendency to treat statutory functions and orders as judicial than have their American counterparts. The matter of categorization of an order is, however, important. For example, orders of certiorari and prohibition will only issue to bodies which are under a duty to act judicially." The Alberta case of Camac Exploration Ltd. v. Oil and Gas Conservation Board of Alberta," which involved an application for certiorari in respect of a well spacing order, indicates that the Conservation Board, at least in its deliberations over spacing orders, is a quasi-judicial body.

Although it appears that some conservation orders of the Provinces of Alberta and Saskatchewan may be considered legislative, while others may be construed as judicial or quasi-judicial, there is little doubt that conceptually, most are legislative in nature. This classification seems warranted because the orders are authorized by the Provincial Legislatures to carry out and give effect to a continuing legislative function assigned to Conservation Boards under standards prescribed by the Legislature. They are prospective, not retroactive, and provide a rule of conduct for the future. Apparent exceptions generally prove to be orders which are incidental to the implementation of earlier prospective orders. Conservation orders are never final in the sense that a judgment of a court is final, and similarly, a conservation order does not confer vested rights that are immune from change, if a change is required to achieve the objects of the conservation statute. ${ }^{-1}$ A Conservation Board has a continuing responsibility to carry out the intent and purposes of the Act under which it is created and cannot be precluded from setting aside, modifying or varying any of its orders. Again, a conservation order that is not beyond the powers of the regulatory agency and is otherwise valid on its face and from which no appeal is taken within the prescribed appeal period is final and binding until set aside." The reversal or setting aside of a conservation order is tantamount to a holding that the order was erroneous or invalid in its inception. In such event it would seem to follow that the rights of the parties should be as they were prior to the granting of the order.

1 R. M. Williarns, Nature and Effect of Conservation Orders (1963), 8 Rocky Mountain Mineral Law Institute 433, at 436.

2 S. A de Smith, Judic:al Review of Administrative Action 42 (1959).

3 (1964) 47 W.W.R. (N.S.) 81. In this Chamber Application the Applicant pleaded. inter alia, that the Conservation Board failed to act judicially in that it did not provide the Applicant with proper notice of the hearing in question. The Respondent relied on Sec. $103(3)$ of the Act. which provided that subject to Sec. 119 of the Act, no proceeding of the Board is removable by certiorari. Kirby, J., apparently Act, no proceeding of the Board is removable by certiorari. Kirby, J., apparentiy the grounds that sufficient notice was given to the Applicant.

4 Supra, n. 1, at 439 .

s Id., at 441 . 
An American author has suggested that a conservation order to be valid must meet the following requirements:

(a) The rule must come within the authority and purpose of the particular Conservation Act.

(b) If the rule is in derogation of the common law, authority for the rule will not be implied.

(c) The rule must be necessary to effectuate the purpose of the Conservation Act.

(d) The rule must be reasonable.

(e) The rule must lay down a standard of conduct which can be reasonably followed.

(f) The rule must be explicit in its requirements so that its meaning may be reasonably comprehended. ${ }^{\circ}$

\section{CIVIL LIABILITY RESULTING FROM VIOLATIONS OF CONSERVATION ORDERS}

The Conservation Acts of Both Alberta and Saskatchewan provide the usual statutory penalties, sanctions and remedies for the violation of Conservation orders. These will not be dealt with herein for the reason that the more significant and contentious of these remedies have been considered at length in a prior paper. Consideration will therefore be directed to the question of what, if any, civil liability results from the violation of a conservation order. The grounds for any such liability to be reviewed herein will be limited to breach of statutory duty and breach of contract."

\section{Breach of Statutory Duty and Negligence}

While a cause of action framed for breach of a statutory duty appears to some extent to overlap with an action framed in negligence, a party seeking redress for injuries or loss sustained through the violation of a conservation order may, depending upon the circumstances of his case and the conservation order violated, conclude that his best chance of success lies in an action based upon the breach of a statutory duty. Such a decision would be particularly appropriate in a case where the party seeking redress concludes that negligence would be difficult to establish. The modern tendency is to treat the two causes of action as independent of one another. ${ }^{\mathrm{B}}$ In negligence the existence of a duty depends upon reasonable foresight, and the duty, if it exists, is always the same, namely, to exercise reasonable care in the circumstances. The existence of a statutory duty on the other hand, depends upon the criteria laid down in the statute itself. ${ }^{\circ}$ Our courts have not had an occasion as yet, however, to consider the applicability of this doctrine to a violation of a conservation order, and indeed, the entire question of common law liability flowing from the breach of a statutory duty is at the best, vague.

6 F. Moulton, Possible Liabilities Arising from Violations of Conservation Orders, (1960) Eleventh Annual Institute on Oil and Gas Law and Taxation 243, at 269.

- See Kennedy, et al, Tort Liability in Waterflood Operations (1966), 5 Alta. L. Rev. 52: and Bredin, Legal Liability for Water Flooding in Petroleum Reservoirs in Alberta (1961), 1 Alta. L. Rev. 516.

s Winfield on Tort, 7 th ed., at 332.

9 Id., at 333 . 
In order to succeed in an action for damages for breach of statutory duty, the plaintiff must establish a breach of a statutory obligation which, in the proper construction of the statute, was intended to be a ground of civil liability to a class of persons of whom he is one. He must establish an injury or damage of a kind against which the statute was designed to give protection, and he must, in addition, establish that the breach of statutory obligation caused or materially contributed to his injury or damage. ${ }^{10}$

Lord Simonds, in Cutler v. Wandsworth Stadium Ltd., ${ }^{11}$ stated that "the only rule which in all circumstances is valid is that the answer [to the question of whether a private right of action exists for breach of a statutory duty] must depend on a consideration of the whole Act and the circumstances, including the pre-existing law in which it was enacted." It thus appears that the question, at least in theory, is one of ascertaining the intention of the legislature. Fortunately, the intention of the Alberta and Saskatchewan Legislatures, to preserve common law rights of action, appears obvious. ${ }^{12}$ The Saskatchewan Act provides that no prosecution under the Act shall deprive a person suffering damage or injury of any cause of action that he may have. The Alberta statute on the other hand, contains the same provision as a subsection to a section devoted entirely to the matter of prosecutions for waste. Some doubt therefore exists as to whether the Alberta Legislature intended to preserve all common law rights of action for violations of conservation orders, or only those resulting from waste as defined in the Act.

Among the criteria to be examined in determining whether the breach of a statutory duty will give rise to a cause of action are the following:

(a) Whether the statute is for the benefit of a particular class.

Doubt concerning the validity of this test, however, was expressed by Atkin, L.J., in Phillips v. Britannia Hygienic Laundry Co., ${ }^{13}$ wherein he stated "it would be strange if a less important duty, which is owed to a section of the public, may be enforced by an action, while a more important duty owed to the public at large cannot."

(b) An examination of the type of harm to be prevented.

If the harm to be prevented is exactly the type of harm which the plaintiff has suffered, there appears to be a strong argument in favour of his right of action. In Monk v. Warbey, ${ }^{14}$ the owner of a car, under a statutory duty to insure the car against the risk of its injuring other persons, not only when the car was in use by the owner, but also any other person using it with his permission, permitted an uninsured party to operate his car. The car was involved in a collision and an action ensued. The Court

1036 Halsbury's Laws 450 (3d ed. Simonds 1955).

11 |1949| A.C. 398 at 407.

1. Oil and Gas Conservation Act, R.S.S. 1965, c. 360, Sec. 61; "A prosecution under this Act does not deprive any person suffering damage or injury of any cause of action he may have."

Oil and Gas Conservation Act, S.A. 1957, c. 63. Sec. 131(1): "Waste is prohibited and any person who commits waste is guilty of an offence under this Act.

(4) A prosecution under this Act does not deprive any person suffering damages or injury prosecution under this Act does have."

13 [1923] 2 K.B. 832 at 841, approved in Monk v. Warbey [1935] 1 K.B. 75

14 [1935] 1 K.B. 75, applied in Corfield v. Groves [1950] 1 All E.R. 488. 
of Appeal held that the very purpose of the provision in the Act was to enable injured third parties to recover for injuries suffered as a result of the negligent driving of uninsured persons. ${ }^{15}$

(c) An examination of the nature of the penalty.

The magnitude of the statutory penalty is sometimes said to indicate the intention of the Legislature that no civil liability should result from the breach of a statutory duty. In Groves v. Wimborne, ${ }^{11}$ the statute in issue provided that the occupier of a factory who did not properly fence dangerous machinery was liable to a fine of one hundred pounds. The Act also provided that the whole or any part of the fine might be applied for the benefit of a person injured by the operator's neglect. It was held in an action for damages brought by a boy whose arm was amputated through contact with an unfenced machine, that he was entitled to damages as, firstly, there was no certainty that he would receive any portion of the fine, and secondly, that it was inconceivable that Parliament meant to limit damages through death or mutilation to the amount of one hundred pounds statutory penalty.

A plaintiff in an action for breach of statutory duty must prove, in addition to the breach, certain other elements of the tort of breach of statutory duty. These are as follows:

(a) that the duty must be owed to the plaintiff.

If the statutory duty is expressed to be limited to a certain class of person for whose benefit they exist, then the plaintiff must prove that he is a member of the protected class.

(b) that the injury must be of the kind that the statute is intended to prevent.

If the object of the statute was to prevent mischief of a particular kind, one who suffers from its non-observance loss of a different kind cannot recover. In the case of Close v. Steel Company of Wales Ltd.," ${ }^{17}$ the House of Lords held that a workman who was injured by a dangerous piece of equipment which flew out of a machine could not recover on the basis of a statutory obligation that dangerous pieces of equipment were to be securely fenced.

(c) that the breach of duty must have caused the damage.

It is clear that an injured person must prove the causal connection between the breach of duty and the damage. In the case of Ginty v. Belmont Building Supplies, Ltd., ${ }^{18}$ the plaintiff working on an asbestos roof did not use the "crawling bars" he was required to use and subsequently fell through the roof. The relevant regulation provided that "crawling boards" shall be used. It was held that the breach of duty consisted of and was coextensive with the wrongful act of the plaintiff in not using the "crawling boards" and he was therefore unsuccessful.

15 For a criticism of this case, see Glanville Williams, The Effect of Penal Legislation in the Law of Tort, (1960) 23 Mod. L. Rev. 233, at 247.

(i) [1898] 2 Q.B. 402

17 [1962] A.C. 367 .

1s [1959] 1 All E.R. 414. 
A review of the American authorities suggests that in certain States a person injured as a result of the violation of a conservation order may, if he was a member of the class intended to be protected, and if, in addition, the injury was of the kind the order was designed to prevent, have a cause of action for breach of a statutory duty. The matter, however, is by no means clear, and in no case does a court appear to have dealt specifically with the question of whether the liability determined resulted from the breach of the statutory duty in question. In each case supportive of the conclusion that a statutory cause of action does lie, the issue was decided on other grounds, for example, negligence. The leading American case is Peterson v. Grayce Oil Co. ${ }^{19}$ In this case the defendants, to increase production, installed a vacuum pump contrary to the provisions of Regulation 40 of the Texas Railroad Commission. ${ }^{20}$ The plaintiffs, who were owners of the adjoining premises, suffered a decrease in production during the time the vacuum pump was in use, and brought action to recover the value of the lost oil. The defendants contended, firstly that Rule 40 furnished no proper basis for the suit because it did not purport to give a private right of action, secondly that the Railroad Commission only had authority to make regulations for the conservation of oil and gas in the interests of the public, and thirdly, that the penalties prescribed by the statute for the violation of the rule precluded a private or individual right of action. The Court of Civil Appeals in its judgment for the plaintiff stated "it is our conclusion that there is no merit in the contention that the alleged violation of Rule 40 of the Railroad Commission could not be made the basis of the plaintiffs' asserted right of recovery of actual damages . ..". ${ }^{21}$ The case was sent back for a new trial on other grounds, and an appeal followed to the Supreme Court of Texas. The Supreme Court reconfirmed the action of the Court of Appeals in sending the case back for a new trial, and stated that there was consequently no need to rule on the authority or the effect of a violation of Rule 40 .

The second case cited as authority for the proposition that liability flows from the breach of a statutory duty is the Texas case of Loeffler v. King.:-2 This case involved, in part, a claim for damages by reason of the fact that the defendant had drilled and produced from three wells which were located less than the $\mathbf{3 3 0}$ feet from the plaintiff's property line as required by a ruling of the Texas Railroad Commission. It was held that the plaintiff had the right to allege a cause of action to recover any oil he may have lost by the defendant's operations. The Court quoted with approval the following portion of the judgment in the case of Elliff v. Texon Drilling Co.;"; "The landowner is privileged to sink as many wells as he desires upon his tract of land and extract therefrom and appropriate all the oil and gas that he may produce, so long as he operates within the spirit and purpose of conservation statutes and orders of the Railroad Commission. ... In this manner, if all operators exercise the same degree of skill and diligence each owner will recover in most

19 37 S.W. (2d) 367 (Tex. Civ. App. 1931), aff'd, 98 S.W. (2d) 781 (1936).

20 See Reg. 705, Saskatchewan Oil and Gas Conservation Regulations, O.C. 2272/68, for a similar prohibition.

21 Supra, n. 19, at 372 .

2228 S.W. 2d 201 (Tex. Civ App. 1950).

23146 Tex. 575, 210 S.W. 2d 558 (1948). 
instances his fair share of the oil and gas." ${ }^{24}$ [Emphasis in the original.]

In the Texas case of Gulf Oil Corporation v. Alexander, ${ }^{25}$ the plaintiff sued for damages for polluted fresh water strata used by him in irrigating his farm lands and recovered judgment. The undisputed findings showed that the defendant's disposal of its salt water polluted the supply of irrigation water. The plaintiff pleaded that the defendant violated Rule 20 of the Railroad Commission ${ }^{26}$ which provided in essence that fresh water shall be protected from pollution There was no evidence of negligence. The court held that the plaintiff was entitled to judgment.

While the reasoning in the Peterson v. Grayce and Loeffler v. King cases, supra, appears cloudy, it is submitted that the decisions were just. In each case the court apparently concluded that the injured party was one of the class and suffered the type of injury which the legislation in question was designed to prevent. Moreover, the conservation orders violated in these cases both appear to have been reasonably necessary to effectuate the stated purposes of the Act. Both of the rules seem reasonable and each laid down a rule of conduct which could easily be followed. It is submitted that our courts, given similar conservation orders to construe might well, in a proper case, find liability on this basis.

The case of Gulf Oil Corporation v. Alexander, supra, however, is more difficult to reconcile. In that case the rule involved was that fresh water "shall be protected from pollution". The established law in Texas at that time placed a duty on an operator to use reasonable care to protect fresh water from pollution, and the issue in the absence of the rule would be one of negligence. It has been submitted that the rule in question was an unreasonable rule in that it did not lay down a standard of conduct that could either be reasonably comprehended or followed. An analogy has been drawn between the rule and a hypothetical rule of a transport commission that "all airplanes shall be so maintained and flown that a crash will not occur." ":

Several American jurisdictions, including Kentucky and Oklahoma, consider the breach of a statutory duty in a more restricted manner and treat such a breach as evidence of negligence per se. ${ }^{2 s}$ In Nisbet v. Van $T u y l,,^{29}$ the lessee in abandoning a dry hole failed to comply with the requisite abandonment regulations. The lessor replugged the hole and sought recovery from the lessee. Recovery was allowed on a theory of negligence per se.

This approach has also been employed in a number of Oklahoma cases $^{30}$ to sustain recovery by the lessor against the operator for pollution of surface water. The statute in question appears to have been construed as a penal statute and violation has been treated as negligence per se. It has been suggested, however, that while the language of these decisions discusses negligence and imports a fault principle, the results

\footnotetext{
24 Supra, n. 22, at 214.

25291 S.W. 2d 792 (Tex. Civ. App. 1956).

21) Rule 20 of the Texas Railroad Commission provides as follows: "Fresh water whether Rule 20 of the Texas Railroad Commission provides as follows: "Fresh water whether
above or below the surface shall be protected from pollution. whether in drilling. plugging or disposing of salt water already produced." Compare with Regs. 703 and 710 of the Alberta Oil and Gas Conservation Regulations, and with Regs. 702 and 810 of the Saskatchewan Oil and Gas Conservation Regulations.

27 Supra, i 6, at 272.

-. See generally, Winfield on Tort, 7 th ed., p. 331

2921 Fed. 2d 874 ( 7 th Cir. 1957).

30 See Zarrow v. Hughes 282 P. $2 d 215$ (Okla. 1955).
} 
seem to come down to strict liability, since justification which is an escape from negligence per $s e$ is seemingly not recognized. ${ }^{31}$

2. Violation of Conservation Order as a Breach of Contract

Another ground for finding civil liability for the violation of a conservation order might well be in an action for breach of contract. Conservation orders in the United States are said to form part of an oil and gas lease and impose duties on lessees that are enforceable by the lessor as well as the State. ${ }^{3:}$ This theory is illustrated by the case of Simpson v. Stanolind Oil and Gas Co. ${ }^{33}$ In this case Stanolind, without prior approval of the Oklahoma Corporation Commission, drilled an off pattern well which it claimed was sufficient to hold its lease, which said lease, except for the drilling of the well, would have expired during the time the well was being drilled. The lessors in their suit contended that, inasmuch as Stanolind did not at the time it drilled the well have necessary Commission approval, the well was an unlawful well in violation of the Commission's orders, and hence the well could not be relied upon to hold the lease. The court, in denying the plaintiff's claim that the State Conservation orders were incorporated into the lease and imposed a duty upon the lessee for the benefit of the lessor, held that the breach of duty complained of had not injured the lessor, but stated, that if damage had resulted (for example, if the regulatory agency had reduced the well allowable because of the violation with a resultant decrease in royalties), the lessor could have recovered on the theory of breach of contract, one term of the lease contract being the obligation to comply with conservation orders.

\section{CONCLUSION}

From the foregoing review it seems reasonable to conclude that a violation of a conservation order may, in certain circumstances, give rise to a cause of action. It is submitted, moreover, that this conclusion is consistent with the avowed intent of the Legislatures of Alberta and Saskachewan. It appears, however, that this result should only follow if the order in question comes within the authority and purpose of the particular statute; is reasonably necessary to effectuate the purpose of the Act; is fair, and lays down a standard of conduct which can be understood and followed. While the form that an action for a violation of a conservation order should take appears to be dependent largely on the type or nature of the conservation order violated, attention should be directed to the possibility of forming the action for breach of statutory duty. Careful consideration of such an action would seem particularly appropriate in cases where the violation in question either prevented or hindered an operator from obtaining his just and equitable share of the production from a pool, or pertained to an act of waste. This cause of action should similarly be considered in cases where a plaintiff concludes that negligence as a cause of action would be difficult to establish. In drafting a cause of action for breach of statutory duty, care should be taken not to overlook the possibility that original common law liability exists alongside statutory liability.

31 See Wilcox Oil Co. v. Walters 284 P. 2nd 726 (Okla. 1955) and Williams and Meyers, Oil and Gas Law, Vol. 5, p. 463.

32 William and Myers, Id., at 461 . See also Sec. 5 and Sec. 49 of the Alberta Oil and Gas Conservation Act.

33114 F. Supp. 731 (E.D. Okla. 1953). 